Document downloaded from:

http://hdl.handle.net/10251/156029

This paper must be cited as:

Rodriguez-Alzueta, O.; Cuquerella Alabort, MC.; Miranda Alonso, MÁ. (2019). Triplet Energy Transfer versus Excited State Cyclization as the Controlling Step in Photosensitized Bipyrimidine Dimerization. The Journal of Organic Chemistry. 84(21):13329-13335. https://doi.org/10.1021/acs.joc.9b01423

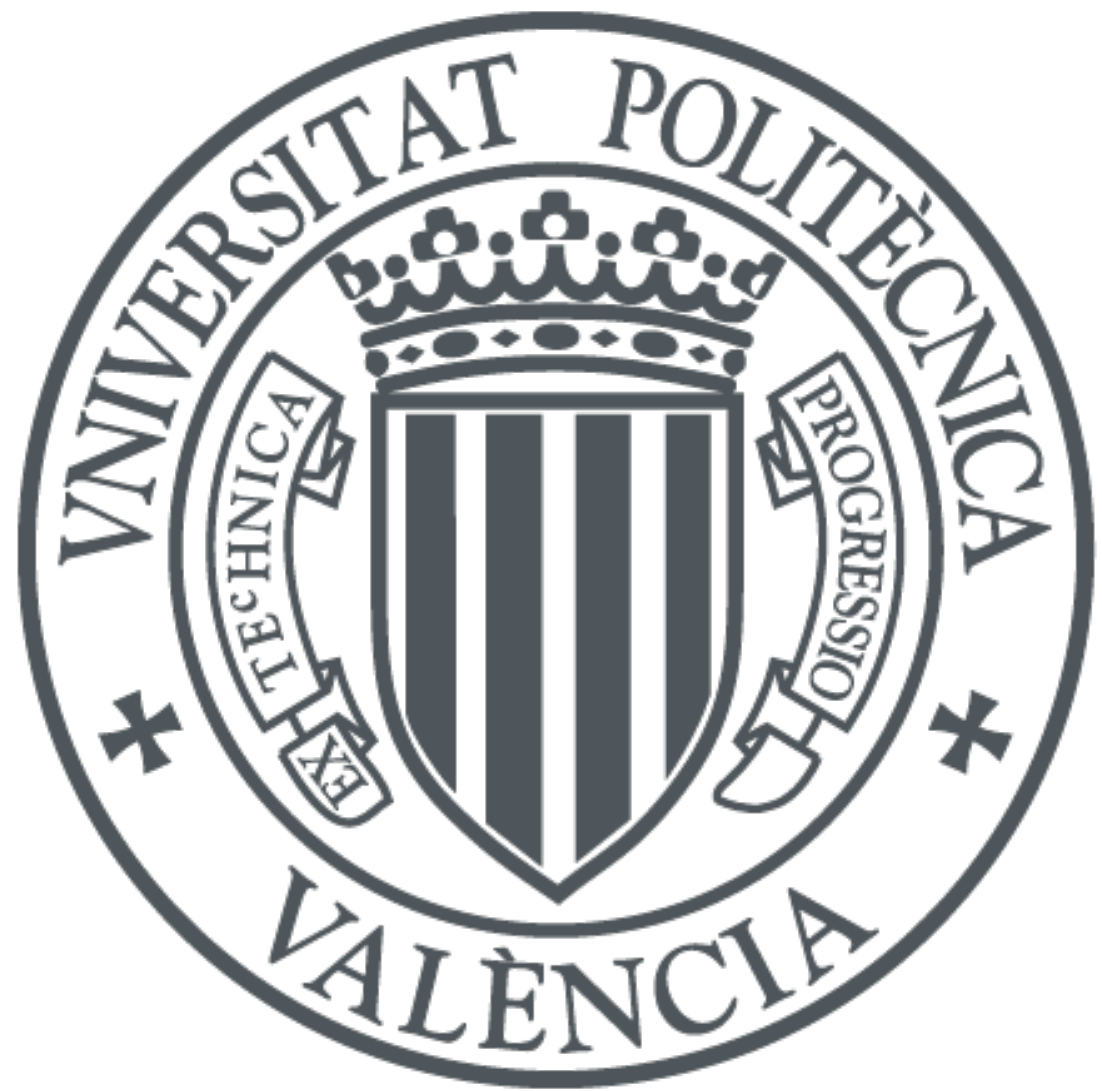

The final publication is available at

https://doi.org/10.1021/acs.joc.9b01423

Copyright American Chemical Society

Additional Information 


\title{
Triplet energy transfer versus excited state cycloaddition as the controlling step in photosensitized bipyrimidine dimerization
}

\author{
Ofelia R. Alzueta, M. Consuelo Cuquerella* and Miguel A. Miranda*
}

aInstituto Universitario Mixto de Tecnología Química, Universitat Politècnica de València (UPV-CSIC), Av. Los Naranjos s/n 46022, Valencia, Spain.e-mail:mmiranda@qim.upv.es, mcuquere@itq.upv.es

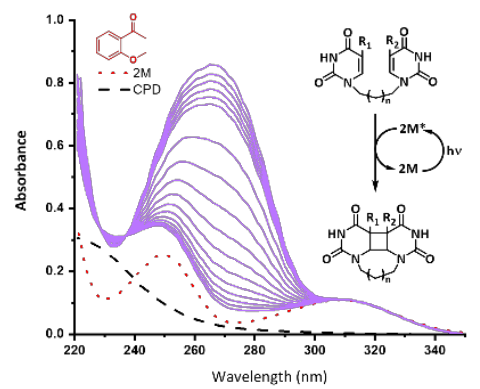

\begin{abstract}
Polymethylene linked homo- and hetero- bipyrimidine models have been designed with different C5 substitution and bridge length. Selective irradiation of 2'-methoxyacetophenone $(2 \mathrm{M})$, with the bipyrimidine models affords cyclobutane pyrimidine dimers, even in the presence of bulky substituents.

Substitution at C5 affects both the triplet energies $\left(E_{T}\right)$ of the pyrimidine (Pyr) derivatives and the steric hindrance towards intermolecular energy transfer and intramolecular triplet Pyr* quenching. Photophysical studies showed that alkyl substitution resulted in a significant decrease of the $\mathrm{E}_{\mathrm{T}}$ value.

Quenching of the triplet excited state of $2 \mathrm{M}$ by the Pyr derivatives was proven, and their quenching rate constants $\left(k_{\mathrm{q}}\right)$ established. As a general trend, the thymine-containing compounds showed $\mathrm{k}_{\mathrm{q}}$ values higher than $10^{9} \mathrm{M}^{-1} \mathrm{~s}^{-1}$ while in the uracil and tert-butyluracil analogues $\mathrm{k}_{\mathrm{q}}$ was markedly lower. These data are explained considering three different scenarios: a) triplet energy transfer is the rate controlling step, b) excited state cyclodimerization is the rate controlling step and, c) the rate controlling step switches along the reaction. Thus, by introducing variations in the substitution at $\mathrm{C} 5$, the length of the linking bridge or the substrate concentration it is possible to switch from a process governed by the intrinsic dimerization step to an energy transfer controlled process.
\end{abstract}




\section{Introduction}

The chemical stability of organic molecules can be compromised upon exposure to light. This is of special relevance for DNA, whose irradiation leads to different types of damage of considerable biological relevance. ${ }^{1-2}$ During the last decades, an intense research effort has been devoted to the elucidation of the underlying photochemical mechanisms. In this context, cyclobutane pyrimidine dimers (CPDs) formation has been intensively investigated, since they represent $75 \%$ of the DNA photolesions produced upon direct sunlight absorption and have been related to the appearance of skin cancer. ${ }^{2-8}$ However, it is well documented that these lesions can also be formed through a triplet photosensitization mechanism. ${ }^{9}$ In this kind of process, a photosensitizing compound reaches its triplet excited state upon absorption of UVA light and subsequent intersystem crossing. When interacting with DNA, the excited photosensitizer may transfer its energy to a pyrimidine (Pyr) unit (Scheme 1, step 1). The resulting Pyr*, can react with a neighboring ground state Pyr leading to CPDs through a formal [2+2]photocycloadditon (Scheme 1, step 2). Photosensitization is a convenient tool to investigate triplet Pyr*-mediated chemistry as formation of the Pyr-singlet excited states is circumvented, thus reducing the mechanistic complexity. ${ }^{9}$

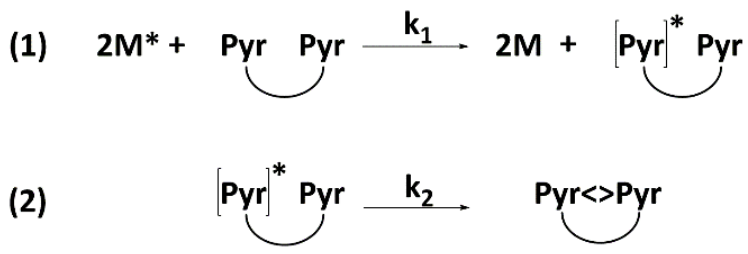

Scheme 1. Steps involved in the photosensitized pyrimidine dimerization to form cyclobutane pyrimidine dimers (CPDs).

The aim of the present work is to determine the nature of the rate controlling step in the photosensitized cyclodimerization of bipyrimidines, making use of C5 substitution in combination with entropic factors related to the length of the linking bridge. To our knowledge this issue has not been previously addressed, in spite of the expected influence of the relative rates of energy transfer versus intrinsic triplet Pyr* dimerization on the overall efficiency of the process. To achieve this goal, polymethylene linked homo- and hetero- bipyrimidine models have been designed with a variety of C5 substitution (Scheme 2, series $\mathbf{3}$ and $\mathbf{5}$ ) and, in one case, different bridge length (compounds $\mathbf{3} \mathbf{b b}$ and $\mathbf{3}^{\mathbf{}} \mathbf{b b}$ ). The monomeric uracil, thymine and tertbutyluracil derivatives 6 have also been included for comparison. Instead of benzophenone, 2'methoxyacetophenone (2M) has been chosen as photosensitizer because: i) it is an efficient 
CPDs photosensitizer ${ }^{10-12}$ and ii) unlike benzophenone, $2 \mathrm{M}$ does not yield any unwanted side process, such as the Paternò-Büchi photoreaction. ${ }^{10-11}$

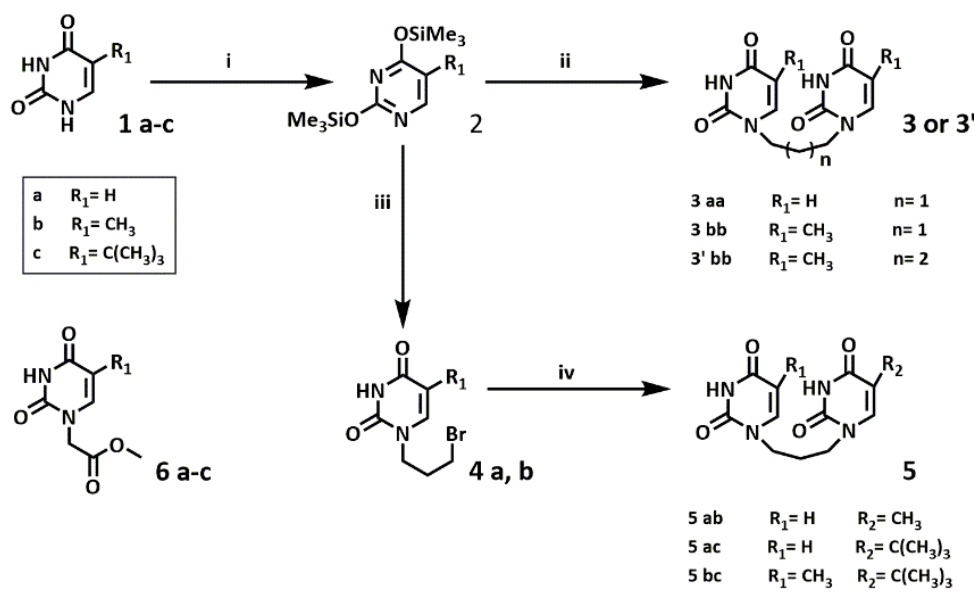

Scheme 2. Synthetic strategy to prepare homo- bipyrimidine models (route $\mathrm{i}+\mathrm{ii}$ ) and hetero- bipyrimidine models (route $\mathrm{i}+\mathrm{iii}+\mathrm{iv}$ ). Reagents and conditions (i) hexamethyldisilazane, chlorotrimethylsilane, $130^{\circ} \mathrm{C}, 2 \mathrm{~h}$; (ii) $1,3-$ dibromopropane or 1,4 -dibromobutane, $\mathrm{DMF}, 170^{\circ} \mathrm{C}, 18 \mathrm{~h}$; (iii) 1,3-dibromopropane, $\mathrm{DMF}, 80^{\circ} \mathrm{C}, 18 \mathrm{~h}$; (iv) 2,4bis(trimethylsilyloxy)pyrimidine (2a-c), DMF, $80^{\circ} \mathrm{C}, 18 \mathrm{~h}$.

\section{Results and Discussion}

\subsection{Synthesis of bipyrimidine models}

To obtain both homo- and hetero- bipyrimidine models the corresponding 2,4bis(trimethylsilyloxy)pyrimidine derivatives (2 a-c) were synthesized in a first stage. Subsequent addition of 0.4 equivalents of 1,3-dibromopropane/1,4-dibromobutane at $170^{\circ} \mathrm{C}$ led to formation of $\mathbf{3}$ or $\mathbf{3}^{\prime}$ (Scheme 2, paths $\mathrm{i}+\mathrm{ii}$ ). When milder reaction conditions $\left(80^{\circ} \mathrm{C}\right)$ were employed, the N1 bromo alkylated Pyr derivatives (4a,b, Scheme 2, paths i + iii) were isolated. Compounds $\mathbf{5}$ were obtained as a result of dropwise addition of $\mathbf{4}$ to the conveniently functionalized Pyr 2 (Scheme 2, path iv). In addition, monomeric methyl pyrimidineacetates were synthesized and purified following the established procedure in bibliography, to be used as reference compounds $(6$, Scheme 2$) \cdot{ }^{13-14}$

\subsection{Steady state photolysis in the presence of 2'-methoxyacetophenone}

As expected, all the UV spectra of the bipyrimidine models displayed a band with its maximum centered at ca. 260-270 $\mathrm{nm}$ and a tail extending up to $c a$. $300 \mathrm{~nm}$, redshifted by 4-7 $\mathrm{nm}$ with respect to the monomeric pyrimidines (Figure S1 in SI). ${ }^{15}$ Irradiation of solutions containing equimolar mixtures of the models and $2 \mathrm{M}$ with lamps emitting in the $310-390 \mathrm{~nm}$ range allowed for selective excitation of $2 \mathrm{M}$, ensuring photosensitization (see Figure $1 \mathrm{~A}$ and $1 \mathrm{~B}$ for 3aa and 5ac). The reaction was monitored by UV spectroscopy, and in all cases a progressive decrease of the absorption in the $240-290 \mathrm{~nm}$ region along with a blue shift in the absolute UV maxima of the mixtures was clearly observed. Conversely, the spectra remained unaltered in the region 
above $300 \mathrm{~nm}$, where the photosensitizer is the only light-absorbing species (Figure $1 \mathrm{~A}$ and $1 \mathrm{~B}$ and Figure S2). This is fully consistent with the disappearance of the enone chromophore of the Pyr bases that occurs when CPDs are formed. As the reactions proceeded the final UV spectrum
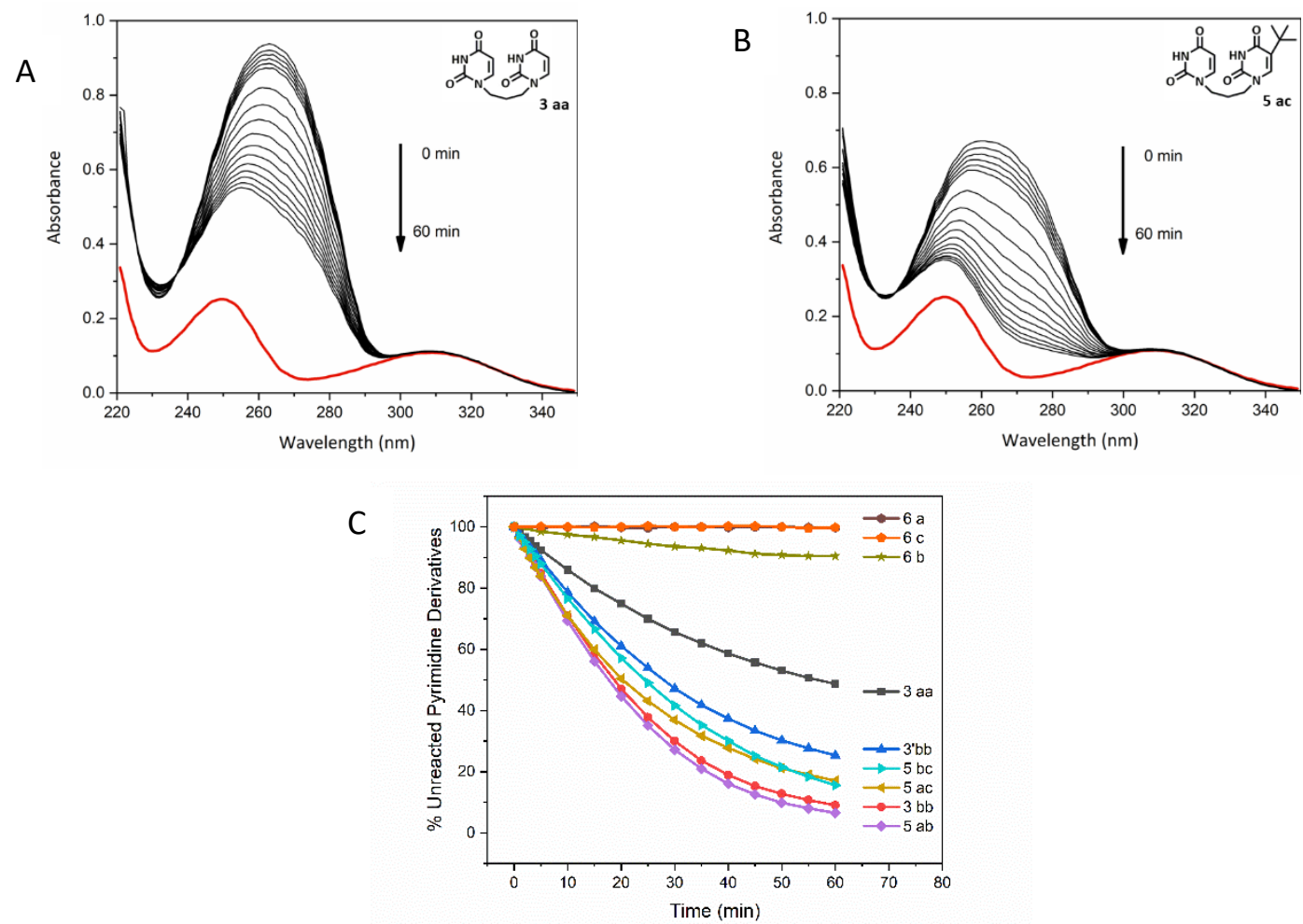

resembled progressively that of $2 \mathrm{M}$, which as expected for a photosensitizer remained unaltered. ${ }^{11}$

Figure 1. 2'-Methoxyacetophenone photosensitized irradiation of A) 3aa and B) 5ac in PBS under deaerated conditions (the spectrum of $2 \mathrm{M}$ in red is included for reference). C) \% of unreacted Pyr models, 3, 3', 5, and $\mathbf{6}$. Monitorization was performed by UV-Vis spectrophotometry at their maximum wavelength.

To secure that cis-syn CPDs were actually the photoproducts, parallel irradiations were run at a larger scale, using either $2 \mathrm{M}$ or acetone as photosensitizers. ${ }^{16}$ The photoproducts were isolated and fully identified by a thorough NMR spectroscopic analysis. Their structures are shown in Figure 2. Parallel experiments were run with the monomers (in the form of pyrimidineacetates 6, Scheme 2) although changing the molar ratio to $2: 1$ in order to maintain the number of chromophores in solution. The kinetics obtained for all the compounds evaluated are presented as percentages of unreacted substrates in Figure 1C. The outcome of these experiments revealed that the intermolecular photoreaction is practically non-existent, while the intramolecular counterpart in the model compounds is efficient (Figure 1C). In addition, the observed reactivity order $(5 a b>3 b b>5 a c>5 b c>3 \prime b b>3 a a)$ revealed the intriguing case of $3 a a$, whose kinetics is much slower than that of the other analogues, in spite of the expectedly lower steric hindrance associated with the lack of a bulky C5 alkyl substituent. As a general trend, the 
process is faster when the bipyrimidine contains a thymine unit (3bb, $\mathbf{5} \mathbf{a b}$ and $\mathbf{5} \mathbf{b c}$ ), but if the polymethylene bridge between the two bases is elongated $\left(\mathbf{3}^{\prime} \mathbf{b} \mathbf{b}\right)$ a decrease in the photoreaction rate is observed. The latter effect was previously observed for the direct and acetone-photosensitized photoreaction and was explained by means of base stacking. In addition, increasing the number of methylene groups from 3 to 4 should be associated with the<smiles>O=C1NC(=O)N2CCCN3C(=O)NC(=O)C4C1C3C42</smiles>

7aa

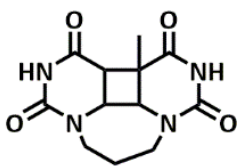

$7 a b$<smiles>CC12C(=O)NC(=O)N3CCCN4C(=O)NC(=O)C1C4C32</smiles>

$7 b b$

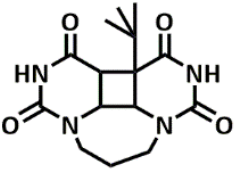

$7 \mathrm{ac}$<smiles>CC12C(=O)NC(=O)N3CCCCN(C(=O)NC1=O)C32</smiles>

7'bb

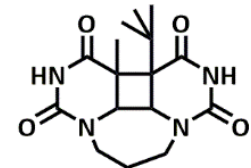

$7 b c$

probability for the model molecule to populate a reactive folded conformation. ${ }^{15-16}$

Figure 2. Structure of the homo- and hetero- cyclobutane pyrimidine dimers (CPDs).

\subsection{Photophysical studies}

As stated above, $2 \mathrm{M}$ photosensitization of the model compounds 3, 3', 5 and 6 led to CPDs formation with substantial variations in their reaction kinetics. In order to explain the observed behavior, a photophysical study was undertaken. Substitution at C5 was expected to affect both the triplet energies $\left(E_{T}\right)$ of the Pyr derivatives and the steric hindrance towards energy transfer and triplet Pyr* quenching ultimately affording the photocycloaddition products (Scheme 1, steps 1 and 2). Based on these considerations, phosphorescence and transient absorption spectroscopic studies were performed to identify the rate determining step. Thus, phosphorescence emission spectra were registered (Figure 3 ) in ethanol matrix at $77 \mathrm{~K}$, and the triplet energies were arbitrarily determined from the wavelength at which the emission raised $20 \%$ of its maximum (Table 1). Clearly, alkyl substitution at C5 resulted in a significant decrease of the $\mathrm{E}_{\mathrm{T}}$ value, which was especially remarkable in the case of the tert-butyl containing compounds. The energy transfer process was investigated in solution, at room temperature, by means of laser flash photolysis upon excitation at $355 \mathrm{~nm}$. The triplet excited state of $2 \mathrm{M}$ was detected as a transient species with maximum at $420 \mathrm{~nm},{ }^{11}$ whose decay was followed in the presence of increasing amounts of the selected Pyr derivatives. In all cases, the triplet lifetime of $2 \mathrm{M}^{*}$ was progressively shortened, in agreement with the expected quenching process (Figure 4 and Figure S3). Plotting the reciprocal lifetimes against quencher concentration allowed establishing the quenching rate constants $\mathrm{k}_{\mathrm{q}}$ (insets Figures 4 and $\mathrm{S} 3$, Table 1 ). 


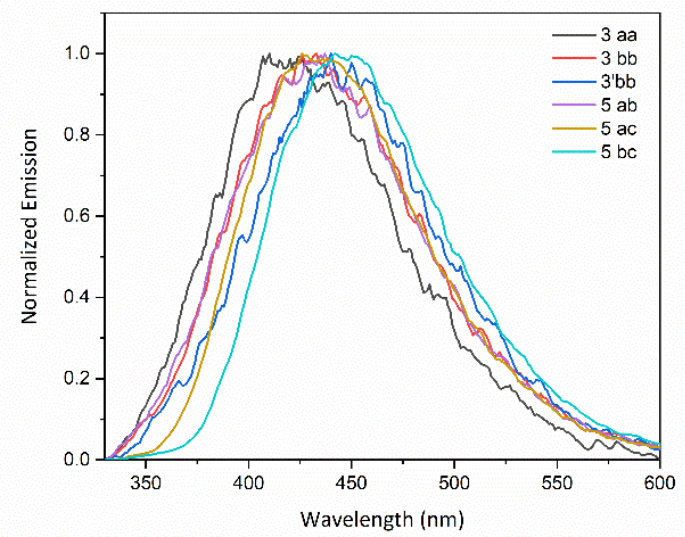

Figure 3. Phosphorescence of the prepared bipyrimidine models (CPDs).

\begin{tabular}{ccc}
\hline Compound & Triplet energy & $\mathbf{k}_{\mathbf{q}}$ \\
\hline 6a & 80.3 & $1.2 \times 10^{8}$ \\
6b & 78.8 & $1.0 \times 10^{9}$ \\
6c & 76.5 & $7.1 \times 10^{7}$ \\
3aa & 80.3 & $3.3 \times 10^{8}$ \\
3bb & 78.6 & $2.7 \times 10^{9}$ \\
3'bb & 76.9 & $2.5 \times 10^{9}$ \\
5ab & 79.2 & $1.9 \times 10^{9}$ \\
5ac & 76.3 & $4.7 \times 10^{8}$ \\
5bc & 73.9 & $1.7 \times 10^{9}$ \\
\hline
\end{tabular}

Table 1. Triplet energies (in $\mathrm{kcal} / \mathrm{mol}$ ) and quenching rate constants (in $\mathrm{M}^{-1} \mathrm{~s}^{-1}$ ) for compounds $\mathbf{3}, \mathbf{5}$ and $\mathbf{6}$.

As a general trend, all the thymine-containing compounds showed $\mathrm{k}_{\mathrm{q}}$ values higher than $10^{9} \mathrm{M}^{-}$ ${ }^{1} \mathrm{~s}^{-1}$. The rate constants determined for the uracil and tert-butyluracil analogues were one order of magnitude lower. This can be attributed to the higher $\mathrm{E}_{\mathrm{T}}$ of the former, according to Sandros' theory, ${ }^{17}$ and to the steric hindrance of the latter. Finally, the process was apparently faster in bipyrimidines than in their corresponding monomeric analogues, but this mainly reflects the different number of nucleobase units at the same molar concentration.

A

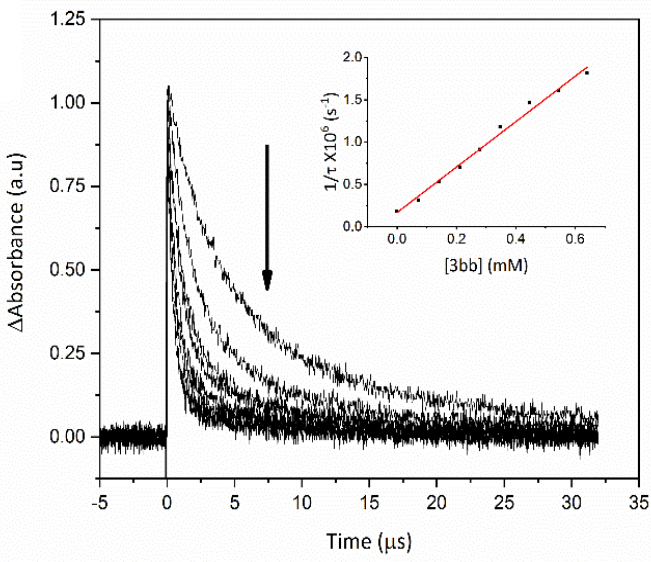

B

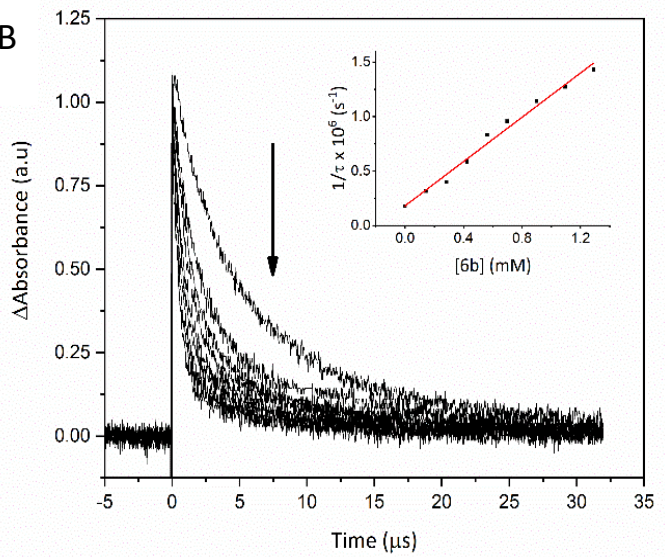

Figure 4. Kinetic decay of $2 \mathrm{M}^{*}$ at $420 \mathrm{~nm}$ in $\mathrm{PB}$ under deaerated conditions after $\mathrm{A}$ ) $\mathbf{3} \mathbf{b b}$ and $\mathrm{B}$ ) $\mathbf{6 b}$ were added (from 0 to $1.3 \mathrm{mM}$ ). Inset) Stern-Volmer quenching of $2 \mathrm{M}^{*}$ by A) $3 \mathbf{b b}$ and B) $6 \mathbf{b}$. 


\subsection{Overall discussion}

At first sight, it seems difficult to establish a satisfactory correlation between the photoreaction rates observed for the steady state photolysis and the photophysical parameters determined by emission measurements and transient absorption spectroscopy. However, all the obtained data can be explained by taking into account that the rate controlling step (1 vs 2 in Scheme 1) switches along the selected series of model compounds. Thus, three different scenarios can be considered, as detailed below.

Triplet energy transfer is the rate controlling step. This is the case for $3 a a$, whose $\mathrm{k}_{\mathrm{q}}$ is relatively low $\left(\mathrm{ca} .3 \times 10^{8} \mathrm{M}^{-1} \mathrm{~s}^{-1}\right)$ and therefore the intermolecular quenching of $2 \mathrm{M}^{*}$ by Pyr becomes the bottleneck for the whole process. As a consequence, the differences that could be expected in the reaction of Pyr* with ground state Pyr associated with steric hindrance play little if any role. Excited state cyclodimerization is the rate controlling step. This is the case of thymine derivatives $5 \mathrm{ab}, \mathbf{3 b b}$ and $\mathbf{5 b c}$, which display $\mathrm{k}_{\mathrm{q}}$ values higher than $10^{9} \mathrm{M}^{-1} \mathrm{~s}^{-1}$. As a result, the relatively slower intramolecular quenching of Pyr* by the other Pyr unit takes over. Accordingly, steric hindrance has a considerable impact on the photoreaction rates, which follow the order $\mathbf{5} \mathbf{a b}>\mathbf{3} \mathbf{b} \mathbf{b}>\mathbf{5} \mathbf{b c}$. Here, one thymine is maintained while the C5 substituent of the other base changes from hydrogen to methyl or tert-butyl along the series. The differences found between $\mathbf{3} \mathbf{b b}$ and $\mathbf{3}^{\mathbf{}} \mathbf{b} \mathbf{b}$ can also be rationalized assuming that excited state cyclodimerization is the rate determining step. However, in this case, the kinetic control is achieved by elongating the linking bridge, which results in a lower probability for the molecule to populate a reactive folded conformation.

The rate controlling step switches along the reaction. Given that triplet energy transfer is an intermolecular process, by contrast with the intramolecular excited state cyclodimerization, the former must be favored at higher concentrations of the bipyrimidine derivative. Thus, it is conceivable that the rate controlling step switches along the reaction, due to the progressively decreasing concentration of unreacted starting material. This is illustrated by the comparison between $\mathbf{5 a c}$ and $\mathbf{5 b c}$. In both cases, the second step is slower at the beginning of the reaction, and hence the photocyclodimerization of $\mathbf{5 a c}$ is faster due to a lower steric hindrance. Conversely, at a later stage the concentration of unreacted material drops considerably, and consequently intermolecular energy transfer becomes the rate controlling step. As a result, $\mathbf{5 b c}$ progresses faster as reflected in Figure $1 \mathrm{C}$ in the crossing of the kinetic plots. 


\section{Conclusions}

The present work has allowed establishing the nature of the rate controlling step in the photosensitized dimerization of bipyrimidine models. By introducing variations in the substitution at $\mathrm{C5}$, the length of the linking bridge or the substrate concentration it is possible to switch from a reaction governed by the intrinsic dimerization step to an energy transfer controlled process.

The presence of a bulky alkyl substituent at C5 results in a decrease of the triplet level, but at the same time increases the steric hindrance. The former effect has a positive impact on the rate of triplet energy transfer, whereas the latter tends to retard both, the energy transfer and the excited state cyclodimerization steps.

\section{Experimental Section}

\subsection{Materials and Methods}

${ }^{1} \mathrm{H},{ }^{13} \mathrm{C}$, and two-dimensional NMR spectra were recorded at $300 \mathrm{~K}$ on a $300 \mathrm{MHz}$ spectrometer; DMSO-d6 was used as solvent, and its signal was taken as a reference: $2.50 \mathrm{ppm}$ for ${ }^{1} \mathrm{H}$ NMR and $39.5 \mathrm{ppm}$ for chemical shift of DMSO-d6 in ${ }^{13} \mathrm{C}-\mathrm{NMR}$. NMR compound's signals were assigned on the basis of two-dimensional NMR measurements (DEPT-135, HSQC and NOESY) being coupling constants given in $\mathrm{Hz}$. Exact mass values were determined by using a QTof spectrometer coupled with a liquid chromatography system with a conditioned autosampler at $10^{\circ} \mathrm{C}$. The separation was carried out on an UPLC BEH C18 column (50 mm x $2.1 \mathrm{~mm}$ i.d., 1,7 $\mu \mathrm{m}$ ). The column temperature was kept at $40^{\circ} \mathrm{C}$. The ESI source was operated in positive ionization mode with the capillary voltage at $1.9 \mathrm{kV}$. The temperature of the source and desolvation was set at 80 and $400^{\circ} \mathrm{C}$ respectively. The cone and desolvation gas flows were 20 and $800 \mathrm{~L} \mathrm{~h}^{-1}$, respectively. All data were collected in centroid mode. Leucine-enkephalin was used as the lock mass generating and $[\mathrm{M}+\mathrm{H}]^{+}$ion $(\mathrm{m} / \mathrm{z} 556.2771)$ at a concentration of $250 \mathrm{pg} / \mathrm{mL}$ and flow rate of $50 \mu \mathrm{L} / \mathrm{min}$ to ensure accuracy during the MS analysis. Solvents were dried according to standard procedures and all reactions were carried out under nitrogen. Commercial chemicals were used without further purification.

\subsection{Synthesis}

\subsubsection{Compounds 2a-c}

Hexamethyldisilazane $(5.8 \mathrm{~mL}, 27.3 \mathrm{mmol})$ and chlorotrimethylsilane $(0.5 \mathrm{~mL}, 4.2 \mathrm{mmol})$ were added to a dry deaerated reaction flask containing uracil $(1 \mathrm{~g}, 8.9 \mathrm{mmol})$. The mixture was stirred for $2 \mathrm{~h}$ at reflux $\left(130^{\circ} \mathrm{C}\right)$, until it turned transparent $(2 \mathrm{a})$. Compound $2 \mathrm{c}$ was prepared from 5 -tertbutyluracil, ${ }^{18}$ following the same procedure. All the obtained compounds were used as 
intermediates for the synthesis of homo- bipyrimidine models ( $\mathbf{3}$ and $\mathbf{3}^{\prime}$ ), bromo alkylated pyrimidine derivatives $(\mathbf{4 a}, \mathbf{b})$ and hetero- bipyrimidine models $(\mathbf{5})$ without isolation as they are air sensitive and hydrolyze readily.

\subsubsection{Compounds 3 and $3^{\prime}$}

Synthesis of $\mathbf{3}$ and $\mathbf{3}^{\prime}$ has been reported by heating 2,4-bis(trimethylsilyloxy)pyrimidines (2a-c) with $\operatorname{Br}\left(\mathrm{CH}_{2}\right)_{n} \mathrm{Br}(\mathrm{n}=3,4)$. To a solution of $\mathrm{O}, \mathrm{O}^{\prime}$-bis(trimethylsilyl)thymine $(2 \mathrm{~b}, 1 \mathrm{~g}, 3.7 \mathrm{mmol})$ in 8 $\mathrm{mL}$ of anhydrous DMF, 1,3-dibromopropane $(0.16 \mathrm{~mL}, 1.6 \mathrm{mmol})$ was added and the stirred mixture heated to $170^{\circ} \mathrm{C}$ overnight. The reaction was cooled to $0^{\circ} \mathrm{C}$ and $10 \mathrm{~mL}$ of water was added to precipitate the product $\mathbf{3 b b}$. The white solid was collected by filtration, washed with a $\mathrm{CHCl}_{3}: \mathrm{MeOH}$ 1:1 mixture and dried under reduced pressure to yield $880 \mathrm{mg}(81 \%)$ of $1, \mathbf{1}^{\prime}-$ (propane-1,3-diyl)bis(5-methylpyrimidine-2,4(1H,3H)-dione) (3bb). ${ }^{1} \mathrm{H}$ NMR (300 MHz, DMSO$\left.\mathrm{d}_{6}\right) \delta_{\mathrm{H}}: 11.20(\mathrm{~s}, 2 \mathrm{H}), 7.51(\mathrm{~s}, 2 \mathrm{H}), 3.64(\mathrm{t}, J=7.1 \mathrm{~Hz}, 4 \mathrm{H}), 1.95-1.83(\mathrm{~m}, 2 \mathrm{H}), 1.73(\mathrm{~s}, 6 \mathrm{H}) .{ }^{13} \mathrm{CNMR}$ (75 MHz, DMSO- $\left.\mathrm{d}_{6}\right): 164.3(2 \mathrm{CO}), 150.9(2 \mathrm{CO}), 141.2(2 \mathrm{CH}), 108.6(2 \mathrm{C}), 44.8\left(2 \mathrm{CH}_{2}\right), 27.9\left(\mathrm{CH}_{2}\right)$, $11.9\left(2 \mathrm{CH}_{3}\right)$. HRMS (ESI-TOF): $\mathrm{m} / \mathrm{z}$ calcd for $\mathrm{C}_{13} \mathrm{H}_{16} \mathrm{~N}_{4} \mathrm{O}_{4}\left[\mathrm{M}+\mathrm{H}^{+}\right]$293.1238, found $\left[\mathrm{M}+\mathrm{H}^{+}\right]$ 293.1250 .

Compound 3aa was prepared following the same procedure described for $\mathbf{3} \mathbf{b b}$. In the case of 3'bb 1,4-dibromobutane was used instead of 1,3-dibromopropane.

1,1'-(Propane-1,3-diyl)bis(pyrimidine-2,4(1H,3H)-dione) (3aa), white solid (67\%). ${ }^{1} \mathrm{H}$ NMR (300 MHz, DMSO-d $\left.\mathrm{d}_{6}\right) \delta_{\mathrm{H}}: 11.24(\mathrm{~s}, 2 \mathrm{H}), 7.65(\mathrm{~d}, J=7.9 \mathrm{~Hz}, 2 \mathrm{H}), 5.54(\mathrm{~d}, J=7.8,2.2 \mathrm{~Hz}, 2 \mathrm{H}), 3.68(\mathrm{t}, J=$ $7.1 \mathrm{~Hz}, 4 \mathrm{H}), 1.89(\mathrm{~m}, 2 \mathrm{H}) .{ }^{13} \mathrm{C}$ NMR (75 MHz, DMSO-d 6 ): 163.7 (2CO), $151.0(2 \mathrm{CO}), 145.5(2 \mathrm{CH})$, $101.0(2 \mathrm{CH}), 45.0\left(2 \mathrm{CH}_{2}\right), 28.0\left(\mathrm{CH}_{2}\right)$. HRMS (ESI-TOF): $\mathrm{m} / \mathrm{z}$ calcd for $\mathrm{C}_{11} \mathrm{H}_{12} \mathrm{~N}_{4} \mathrm{O}_{4}\left[\mathrm{M}+\mathrm{H}^{+}\right]$265.0946, found $\left[\mathrm{M}+\mathrm{H}^{+}\right] 265.0937$.

1,1'-(Butane-1,4-diyl)bis(5-methylpyrimidine-2,4(1H,3H)-dione) (3'bb), pale yellow solid (75\%). ${ }^{1} \mathrm{H}$ NMR (300 MHz, DMSO-d $\left.\mathrm{d}_{6}\right) \delta_{\mathrm{H}}: 11.21(\mathrm{~s}, 2 \mathrm{H}), 7.56-7.47(\mathrm{~m}, 2 \mathrm{H}), 3.63(\mathrm{~d}, J=6.1 \mathrm{~Hz}$, 4H), $1.73(\mathrm{~s}, 6 \mathrm{H}), 1.54$ (d, J = 6.2 Hz, 4H). ${ }^{13} \mathrm{C}$ NMR (75 MHz, DMSO-d 6 ): 164.3 (2CO), 151.0 (2CO), $141.4(2 \mathrm{CH}), 108.5(2 \mathrm{C}), 46.7\left(2 \mathrm{CH}_{2}\right), 25.4\left(2 \mathrm{CH}_{2}\right), 12.0\left(2 \mathrm{CH}_{3}\right)$. HRMS (ESI-TOF): m/z calcd for $\mathrm{C}_{14} \mathrm{H}_{18} \mathrm{~N}_{4} \mathrm{O}_{4}\left[\mathrm{M}+\mathrm{H}^{+}\right]$307.1398, found $\left[\mathrm{M}+\mathrm{H}^{+}\right]$307.1406.

\subsubsection{Compounds $4 a, b$}

Compounds $\mathbf{4 a}$ and $\mathbf{4 b}$ were synthesized by 2,4 -bis(trimethylsilyloxy)pyrimidines $(2 \mathrm{a}, \mathrm{b})$ alkylation after treatment with an excess of 1,3-dibromopropane in DMF. To a magnetically stirred solution of $2 \mathrm{~b}(1 \mathrm{~g}, 3.7 \mathrm{mmol})$ in anhydrous DMF $(2 \mathrm{~mL}), 1,3$-dibromopropane (1,13 $\mathrm{mL}$, $11.1 \mathrm{mmol}$ ) was added and the reaction heated at $80^{\circ} \mathrm{C}$ during $18 \mathrm{~h}$. The reaction was cooled to $0^{\circ} \mathrm{C}$ and water was added to precipitate undesired unreacted thymine or little amounts of $\mathbf{3 b b}$. 
The solid was filtered and the brown solution extracted with dichloromethane. Organic layers were washed with water and brine. After drying with magnesium sulfate the solvent was evaporated and the crude purified by flash chromatography $\left(\mathrm{SiO}_{2}\right.$, cyclohexane/ ethyl acetate 1:3) to afford compound $\mathbf{4 b}$ as a pale yellow solid (600 mg, 66\%). 1-(3-Bromopropyl)-5methylpyridine-2,4(1H,3H)-dione (4b). ${ }^{1} \mathrm{H}$ NMR (300 MHz, DMSO-d $\left.{ }_{6}\right) \delta_{H}: 11.22(\mathrm{~s}, 1 \mathrm{H}), 7.48$ (d, $J=1.3 \mathrm{~Hz}, 1 \mathrm{H}), 3.73(\mathrm{t}, J=7.0 \mathrm{~Hz}, 2 \mathrm{H}), 3.51(\mathrm{t}, J=6.6 \mathrm{~Hz}, 2 \mathrm{H}), 2.12(\mathrm{~m}, 2 \mathrm{H}), 1.74(\mathrm{~d}, J=1.2 \mathrm{~Hz}$, 3H). ${ }^{13} \mathrm{C}$ NMR (75 MHz, DMSO-d $\left.\mathrm{d}_{6}\right) 164.3$ (CO), 150.9 (CO), $141.3(\mathrm{CH}), 108.6$ (C), $46.2\left(\mathrm{CH}_{2}\right), 31.5$ $\left(\mathrm{CH}_{2}\right), 31.3\left(\mathrm{CH}_{2}\right), 11.9\left(\mathrm{CH}_{2}\right)$. HRMS (ESI-TOF): $\mathrm{m} / \mathrm{z}$ calcd for $\mathrm{C}_{8} \mathrm{H}_{11} \mathrm{BrN}_{2} \mathrm{O}_{2}\left[\mathrm{M}+\mathrm{H}^{+}\right] 232.9926$, found $\left[\mathrm{M}+\mathrm{H}^{+}\right] 232.9928$.

1-(3-Bromopropyl)pyrimidine-2,4(1H,3H)-dione (4a), pale yellow solid (57\%). ${ }^{1} \mathrm{H}$ NMR (300 MHz, DMSO-d $\left.)_{6}\right) \delta_{\mathrm{H}}: 11.25(\mathrm{~s}, 1 \mathrm{H}), 7.60(\mathrm{~d}, J=7.8 \mathrm{~Hz}, 1 \mathrm{H}), 5.55(\mathrm{dd}, J=7.8,2.3 \mathrm{~Hz}, 1 \mathrm{H}), 3.76(\mathrm{t}, J$ $=6.9 \mathrm{~Hz}, 2 \mathrm{H}), 3.51(\mathrm{t}, J=6.6 \mathrm{~Hz}, 2 \mathrm{H}), 2.13(\mathrm{~m}, 2 \mathrm{H}) .{ }^{13} \mathrm{C}$ NMR $(75 \mathrm{MHz}$, DMSO-d 6 ): 163.7 (CO), $150.9(\mathrm{CO}), 145.6(\mathrm{CH}), 101.0(\mathrm{CH}), 46.5\left(\mathrm{CH}_{2}\right), 31.3\left(\mathrm{CH}_{2}\right), 31.2\left(\mathrm{CH}_{2}\right)$. HRMS (ESI-TOF): m/z calcd for $\mathrm{C}_{7} \mathrm{H}_{9} \mathrm{BrN}_{2} \mathrm{O}_{2}\left[\mathrm{M}+\mathrm{H}^{+}\right]$247.0082, found $\left[\mathrm{M}+\mathrm{H}^{+}\right] 247.0081$.

\subsubsection{Compounds 5}

Hetero- bipyrimidine compounds (5ab, $5 \mathbf{a c}$ and $\mathbf{5} \mathbf{b c}$ ) were prepared by linking the corresponding bromo alkylated pyrimidine derivative $(\mathbf{4 a , b})$ to a 2,4-bis(trimethylsilyloxy)pyrimidine compound (2a-c).To a solution of $\mathrm{O}, \mathrm{O}^{\prime}$-bis(trimethylsilyl)thymine (2b, $1 \mathrm{~g}, 3.7 \mathrm{mmol}$ ) in $15 \mathrm{~mL}$ of anhydrous DMF, 4a $(0.9 \mathrm{~g}, 4.1 \mathrm{mmol})$ was added and the stirred mixture heated at reflux $\left(80^{\circ} \mathrm{C}\right)$ overnight. Water was added to the cooled reaction $\left(0^{\circ} \mathrm{C}\right)$, precipitating the product $5 \mathbf{a b}$. The white solid was filtered and washed several times with a chloroform: methanol 1:1 mixture and dried under vacuum to obtain 1-(3-(2,4-dioxo-3,4-dihydropyridin-1(2H)-yl)propyl)-5methylpyridine-2,4 (1H, 3H)-dione (5ab) (430 mg, 43\%) . ${ }^{1} \mathrm{H}$ NMR (300 MHz, DMSO-d $\mathrm{d}_{6}$ ) $\delta_{\mathrm{H}}: 11.23$ $(\mathrm{s}, 2 \mathrm{H}), 7.65(\mathrm{~d}, J=7.8 \mathrm{~Hz}, 1 \mathrm{H}), 7.53(\mathrm{~s}, 1 \mathrm{H}), 5.54(\mathrm{~d}, J=7.8 \mathrm{~Hz}, 1 \mathrm{H}), 3.66(\mathrm{q}, J=7.7 \mathrm{~Hz}, 4 \mathrm{H}), 1.88$ $(\mathrm{m}, 2 \mathrm{H}), 1.73(\mathrm{~s}, 3 \mathrm{H}) .{ }^{13} \mathrm{C}$ NMR (75 MHz, DMSO-d $\left.\mathrm{d}_{6}\right): 164.3$ (CO), 163.8 (CO), 151.0 (CO), 151.0 (CO), $145.5(\mathrm{CH}), 141.3(\mathrm{CH}), 108.6(\mathrm{CH}), 101.0(\mathrm{C}), 45.1\left(\mathrm{CH}_{2}\right), 44.7\left(\mathrm{CH}_{2}\right), 28.0\left(\mathrm{CH}_{2}\right), 12.0\left(\mathrm{CH}_{3}\right)$. HRMS (ESI-TOF): $\mathrm{m} / \mathrm{z}$ calcd for $\mathrm{C}_{12} \mathrm{H}_{14} \mathrm{~N}_{4} \mathrm{O}_{4}\left[\mathrm{M}+\mathrm{H}^{+}\right]$279.1094, found [M+H $\left.\mathrm{H}^{+}\right] 279.1093$.

5-(tert-Butyl)-1-(3-(2,4-dioxo-3,4-dihydropyrimidin-1(2H)-yl)propyl)pyrimidine-2,4(1H,3H)dione (5ac) (23 \%). ${ }^{1} \mathrm{H}$ NMR (300 MHz, DMSO-d $\left.{ }_{6}\right) \delta_{\mathrm{H}}: 11.15$ (d, J = 38.4 Hz, 2H), 7.64 (d, J = 7.9 Hz, 1H), $7.32(\mathrm{~s}, 1 \mathrm{H}), 5.54(\mathrm{dd}, J=7.8,1.5 \mathrm{~Hz}, 1 \mathrm{H}), 3.69(\mathrm{td}, J=7.0,4.4 \mathrm{~Hz}, 4 \mathrm{H}), 1.90(\mathrm{~m}, 2 \mathrm{H}), 1.20(\mathrm{~s}$, 9H). ${ }^{13} \mathrm{C}$ NMR (75 MHz, DMSO-d 6 ): 163.7 (CO), 163.0 (CO), 151.0 (CO), 150.7 (CO), 145.5 (CH), $139.9(\mathrm{CH}), 120.3(2 \mathrm{C}), 101.0(\mathrm{CH}), 45.0\left(2 \mathrm{CH}_{2}\right), 32.5(\mathrm{C}), 28.6\left(3 \mathrm{CH}_{3}\right), 28.0\left(\mathrm{CH}_{2}\right) . \mathrm{HRMS}(\mathrm{ESI}-\mathrm{TOF})$ : $\mathrm{m} / \mathrm{z}$ calcd for $\mathrm{C}_{15} \mathrm{H}_{20} \mathrm{~N}_{4} \mathrm{O}_{4}\left[\mathrm{M}+\mathrm{H}^{+}\right]$321.1557, found $\left[\mathrm{M}+\mathrm{H}^{+}\right] 321.1563$. 
5-(tert-Butyl)-1-(3-(5-methyl-2,4-dioxo-3,4-dihydropyridin-1(2H)-yl)propyl)pyrimidine-

2,4(1H,3H)-dione (5bc) (28\%). ${ }^{1} \mathrm{H}$ NMR (300 MHz, DMSO-d 6 ) $\delta \mathrm{H:} 11.17$ (d, J = 33.1 Hz, 2H), 7.51 (d, $J=1.4 \mathrm{~Hz}, 1 \mathrm{H}), 7.33(\mathrm{~s}, 1 \mathrm{H}), 3.67(\mathrm{dt}, J=13.8,6.9 \mathrm{~Hz}, 4 \mathrm{H}), 1.90(\mathrm{~m}, 2 \mathrm{H}), 1.74(\mathrm{~d}, J=1.1 \mathrm{~Hz}$, 3H), 1.20 (s, 9H). ${ }^{13} \mathrm{C}$ NMR (75 MHz, DMSO-d 6 ) $\delta 164.3$ (CO), 163.0 (CO), 151.0 (CO), 150.7 (CO), $141.2(\mathrm{CH}), 139.9(\mathrm{CH}), 120.3(\mathrm{C}), 108.6(\mathrm{C}), 45.1\left(\mathrm{CH}_{2}\right), 44.8\left(2 \mathrm{CH}_{2}\right), 32.4(\mathrm{C}), 28.6\left(3 \mathrm{CH}_{3}\right), 27.9$ $\left(\mathrm{CH}_{2}\right), 11.9\left(\mathrm{CH}_{3}\right)$. HRMS (ESI-TOF): $\mathrm{m} / \mathrm{z}$ calcd for $\mathrm{C}_{16} \mathrm{H}_{22} \mathrm{~N}_{4} \mathrm{O}_{4}\left[\mathrm{M}+\mathrm{H}^{+}\right] 335.1719$, found $\left[\mathrm{M}+\mathrm{H}^{+}\right]$ 335.1704 .

\subsection{Irradiation procedures}

\subsubsection{Photosensitized irradiation with acetone in $\mathrm{H}_{2} \mathrm{O}$}

Solutions of compounds 3 and $\mathbf{5}(0.2 \mathrm{mmol})$ in $180 \mathrm{~mL}$ of deionized water were boiled to increase the solubility and then cooled while bubbling $\mathrm{N}_{2}$ in pyrex erlenmeyer flasks. To the solutions, 20 $\mathrm{mL}$ of HPLC grade acetone was added as photosensitizer and irradiated in a multilamp photoreactor with 14 lamps emitting light centered at $300 \mathrm{~nm}$ during $7.5 \mathrm{~h}$. The progress of the reaction was monitored by using a UV-Vis spectrophotometer following the disappearance of the $260-270 \mathrm{~nm}$ band corresponding to unreacted starting material band. Once the reaction was completed the solvent was evaporated under vacuum obtaining the cis-syn CPDs, 7.

Hexahydro-1H-3a,5,8,9a-tetraazacyclohepta[def]biphenylene-4,6,7,9(5H,8H)-tetraone (7aa), white solid. ${ }^{1} \mathrm{H}$ NMR $\left(300 \mathrm{MHz}, \mathrm{DMSO}-\mathrm{d}_{6}\right) \delta_{\mathrm{H}}: 10.28(\mathrm{~s}, 2 \mathrm{H}), 4.23-4.04(\mathrm{~m}, 4 \mathrm{H}), 3.83(\mathrm{dd}, J=7.0$, 3.4 Hz, 2H), 2.77 (ddd, J = 14.6, 12.0, $2.5 \mathrm{~Hz}, 2 \mathrm{H}), 1.94-1.72(\mathrm{~m}, 1 \mathrm{H}), 1.48(\mathrm{~d}, J=14.6 \mathrm{~Hz}, 1 \mathrm{H})$. ${ }^{13} \mathrm{C}$ NMR (75 MHz, DMSO-d $\left.\mathrm{d}_{6}\right): 166.2$ (2CO), 150.9 (2CO), $54.4(2 \mathrm{CH}), 46.8\left(2 \mathrm{CH}_{2}\right), 36.7(2 \mathrm{CH}), 24.1$ (2 $\mathrm{CH}_{2}$ ). HRMS (ESI-TOF): $\mathrm{m} / \mathrm{z}$ calcd for $\mathrm{C}_{11} \mathrm{H}_{13} \mathrm{~N}_{4} \mathrm{O}_{4}\left[\mathrm{M}+\mathrm{H}^{+}\right] 265.0937$, found [M+H $\left.\mathrm{H}^{+}\right] 265.0932$.

6a,6b-Dimethylhexahydro-1H-3a,5,8,9a-tetraazacyclohepta[def] biphenylene-4,6,7,9 $(5 \mathrm{H}, 8 \mathrm{H})$ tetraone (7bb), white solid. ${ }^{1} \mathrm{H}$ NMR (300 MHz, DMSO-d $\left.\mathrm{d}_{6}\right), \delta_{\mathrm{H}}: 10.28(\mathrm{~s}, 2 \mathrm{H}), 4.08(\mathrm{dt}, J=14.2$, $3.9 \mathrm{~Hz}, 2 \mathrm{H}), 3.91(\mathrm{~s}, 2 \mathrm{H}), 2.81-2.66(\mathrm{~m}, 2 \mathrm{H}), 1.95-1.80(\mathrm{~m}, 1 \mathrm{H}), 1.56-1.44(\mathrm{~m}, 1 \mathrm{H}), 1.38(\mathrm{~s}$, $6 \mathrm{H}) .{ }^{13} \mathrm{C} \mathrm{NMR}\left(75 \mathrm{MHz}, \mathrm{DMSO}-\mathrm{d}_{6}\right): 169.7(\mathrm{CO}), 150.9(\mathrm{CO}), 59.8(2 \mathrm{CH}), 46.6\left(2 \mathrm{CH}_{2}\right), 44.7(2 \mathrm{C}), 23.5$ $\left(\mathrm{CH}_{2}\right), 20.0\left(2 \mathrm{CH}_{3}\right)$. HRMS (ESI-TOF): $\mathrm{m} / \mathrm{z}$ calcd for $\mathrm{C}_{13} \mathrm{H}_{17} \mathrm{~N}_{4} \mathrm{O}_{4}\left[\mathrm{M}+\mathrm{H}^{+}\right]$293.1250, found $\left[\mathrm{M}+\mathrm{H}^{+}\right]$ 293.1241.

\section{7a,7b-Dimethyloctahydro-4a,6,9,10a-tetraazacycloocta[def]biphenylene-5,7,8,10}

$(6 \mathrm{H}, 9 \mathrm{H})-$ tetraone (7'bb), white solid. ${ }^{1} \mathrm{H}$ NMR (300 MHz, DMSO- $\left.\mathrm{d}_{6}\right) \delta_{\mathrm{H}}: 10.23(\mathrm{~s}, 2 \mathrm{H}), 4.08(\mathrm{~d}, J=13.7 \mathrm{~Hz}$, 2H), $3.87(\mathrm{~s}, 2 \mathrm{H}), 2.63(\mathrm{~d}, J=13.8 \mathrm{~Hz}, 2 \mathrm{H}), 1.62(\mathrm{~s}, 4 \mathrm{H}), 1.34(\mathrm{~s}, 6 \mathrm{H}) .{ }^{13} \mathrm{C}$ NMR $\left(75 \mathrm{MHz}, \mathrm{DMSO}-\mathrm{d}_{6}\right)$ : $169.9(2 \mathrm{CO}), 152.2(2 \mathrm{CO}), 59.8(2 \mathrm{CH}), 47.4\left(2 \mathrm{CH}_{2}\right), 46.4(2 \mathrm{C}), 25.4\left(2 \mathrm{CH}_{2}\right), 18.9\left(2 \mathrm{CH}_{3}\right)$. HRMS (ESITOF): $\mathrm{m} / \mathrm{z}$ calcd for $\mathrm{C}_{14} \mathrm{H}_{19} \mathrm{~N}_{4} \mathrm{O}_{4}\left[\mathrm{M}+\mathrm{H}^{+}\right]$307.1406, found $\left[\mathrm{M}+\mathrm{H}^{+}\right] 307.1392$.

6b-Methylhexahydro-1H-3a,5,8,9a-tetraazacyclohepta[def]biphenylene-4,6,7,9(5H,8H)tetraone (7ab), white solid. ${ }^{1} \mathrm{H}$ NMR (300 MHz, DMSO-d $\left.)_{6}\right) \delta_{\mathrm{H}}: 10.28$ (d, J $=6.5 \mathrm{~Hz}, 2 \mathrm{H}$ ), 4.26 (dd, 
$J=9.7,5.8 \mathrm{~Hz}, 1 \mathrm{H}), 4.18-3.99(\mathrm{~m}, 2 \mathrm{H}), 3.91(\mathrm{~d}, J=5.8 \mathrm{~Hz}, 1 \mathrm{H}), 3.39(\mathrm{~s}, 1 \mathrm{H}), 2.75(\mathrm{t}, J=12.6 \mathrm{~Hz}$, 2H), 1.84 (dd, $J=25.5,12.1 \mathrm{~Hz}, 1 \mathrm{H}), 1.56(\mathrm{~s}, 3 \mathrm{H}), 1.49$ (d, J = $17.1 \mathrm{~Hz}, 1 \mathrm{H}) .{ }^{13} \mathrm{C}$ NMR $(75 \mathrm{MHz}$, DMSO- $\mathrm{d}_{6}$ ): 168.6 (CO), 166.1 (CO), 150.9 (CO), $150.8(\mathrm{CO}), 61.0(\mathrm{CH}), 51.8(\mathrm{CH}), 46.7\left(2 \mathrm{CH}_{2}\right), 44.3$ (CH), 42.9 (C), $25.1\left(\mathrm{CH}_{3}\right), 23.8\left(\mathrm{CH}_{2}\right)$. HRMS (ESI-TOF): $\mathrm{m} / \mathrm{z}$ calcd for $\mathrm{C}_{12} \mathrm{H}_{15} \mathrm{~N}_{4} \mathrm{O}_{4}\left[\mathrm{M}+\mathrm{H}^{+}\right]$279.1093, found $\left[\mathrm{M}+\mathrm{H}^{+}\right] 279.1081$.

6b-(tert-Butyl)hexahydro-1H-3a,5,8,9a-tetraazacyclohepta[def]biphenylene-4,6,7,9(5H,8H)tetraone (7ac), white solid. ${ }^{1} \mathrm{H}$ NMR $\left(300 \mathrm{MHz}\right.$, DMSO- $\left.\mathrm{d}_{6}\right) \delta_{\mathrm{H}}: 10.30(\mathrm{~s}, 1 \mathrm{H}), 10.21(\mathrm{~s}, 1 \mathrm{H}), 4.23(\mathrm{~d}$, $J=6.2 \mathrm{~Hz}, 1 \mathrm{H}), 4.16-4.04(\mathrm{~m}, 2 \mathrm{H}), 3.99(\mathrm{dd}, J=9.5,6.2 \mathrm{~Hz}, 1 \mathrm{H}), 3.50(\mathrm{~d}, J=9.5 \mathrm{~Hz}, 1 \mathrm{H}), 2.94-$ $2.82(\mathrm{~m}, 1 \mathrm{H}), 2.81-2.68(\mathrm{~m}, 1 \mathrm{H}), 1.79(\mathrm{~d}, J=14.1 \mathrm{~Hz}, 1 \mathrm{H}), 1.53(\mathrm{~d}, J=14.4 \mathrm{~Hz}, 1 \mathrm{H}), 1.05(\mathrm{~s}, 9 \mathrm{H})$. ${ }^{13} \mathrm{C}$ NMR (75 MHz, DMSO-d $\mathrm{d}_{6}$ ): 168.3 (CO), 166.2 (CO), 150.8 (CO), 150.7 (CO), 56.0 (CH), 54.8 (C), $51.8(\mathrm{CH}), 46.8\left(\mathrm{CH}_{2}\right), 46.0\left(\mathrm{CH}_{2}\right), 38.0(\mathrm{CH}), 35.8(\mathrm{C}), 25.1\left(3 \mathrm{CH}_{3}\right), 24.3\left(\mathrm{CH}_{2}\right)$. HRMS (ESI-TOF): $\mathrm{m} / \mathrm{z}$ calcd for $\mathrm{C}_{15} \mathrm{H}_{21} \mathrm{~N}_{4} \mathrm{O}_{4}\left[\mathrm{M}+\mathrm{H}^{+}\right]$321.1563, found $\left[\mathrm{M}+\mathrm{H}^{+}\right] 321.1556$.

6b-(tert-Butyl)-6a-methylhexahydro-1H-3a,5,8,9a-tetraazacyclohepta[def]biphenylene-

4,6,7,9(5H,8H)-tetraone (7bc), white solid. ${ }^{1} \mathrm{H}$ NMR (300 MHz, DMSO-d 6 ) $\delta_{\mathrm{H}}: 10.34(\mathrm{~s}, 1 \mathrm{H}), 10.11$ (s, 1H), $4.41(\mathrm{~d}, J=6.7 \mathrm{~Hz}, 1 \mathrm{H}), 4.07(\mathrm{dd}, J=11.7,7.2 \mathrm{~Hz}, 1 \mathrm{H}), 3.97(\mathrm{dt}, J=14.5,4.4 \mathrm{~Hz}, 1 \mathrm{H}), 3.75$ (d, J = 6.7 Hz, 1H), 2.93 (ddd, $J=13.6,10.0,3.3 \mathrm{~Hz}, 1 \mathrm{H}$ ), 2.81 (td, $J=12.0,11.2,5.9 \mathrm{~Hz}, 1 \mathrm{H}$ ), 1.94 - $1.78(\mathrm{~m}, 1 \mathrm{H}), 1.62(\mathrm{~s}, 1 \mathrm{H}), 1.57$ (s, 3H), $1.11(\mathrm{~s}, 9 \mathrm{H}) .{ }^{13} \mathrm{C}$ NMR (75 MHz, DMSO-d $)$ : 169.5 (CO), $169.3(\mathrm{CO}), 151.5(\mathrm{CO}), 150.8(\mathrm{CO}), 59.9(\mathrm{CH}), 56.5(2 \mathrm{C}), 55.1(\mathrm{CH}), 46.3\left(\mathrm{CH}_{2}\right), 45.8\left(\mathrm{CH}_{2}\right), 45.8$ $\left(\mathrm{CH}_{2}\right), 36.7(\mathrm{C}), 27.6\left(3 \mathrm{CH}_{3}\right), 23.5\left(\mathrm{CH}_{2}\right), 22.3\left(\mathrm{CH}_{3}\right)$. HRMS (ESI-TOF): m/z calcd for $\mathrm{C}_{16} \mathrm{H}_{23} \mathrm{~N}_{4} \mathrm{O}_{4}$ $\left[\mathrm{M}+\mathrm{H}^{+}\right]$335.1719, found $\left[\mathrm{M}+\mathrm{H}^{+}\right] 335.1704$.

\subsubsection{2'-Methoxyacetophenone photosensitized irradiation}

For analytical purposes, irradiations were performed in quartz cuvettes using a multilamp photoreactor with two opposing lamps emitting in the $310-390 \mathrm{~nm}$ range (with a maximum at $350 \mathrm{~nm}$ ). A $0.04 \mathrm{mM}$ solution of 2M in PBS $10 \mathrm{mM}$ was prepared and compounds $\mathbf{3 , 5}$ or $\mathbf{6}$ added to $172 \mathrm{~mL}$ of this solution in order to have the same concentration as $2 \mathrm{M}$. All the solutions were bubbled with $\mathrm{N}_{2}$ prior to light exposure during $10 \mathrm{~min}$ and the progress of the reaction was monitored by using a UV-Vis spectrophotometer. 2'-Methoxyacetophenone stock solution was used as a reference.

Preparative irradiations were accomplished in a pyrex erlenmeyer flask using a multilamp photoreactor with six opposing lamps emitting light centered at $350 \mathrm{~nm}$. To $500 \mathrm{~mL}$ of miliQ water compounds 3 or $\mathbf{6}$ were added $(0.02 \mathrm{mmol})$ and the solution boiled. Then it was cooled bubbling $\mathrm{N}_{2}$ and $2 \mathrm{M}$ added $(3.2 \mu \mathrm{L}, 0.02 \mathrm{mmol})$. The progress of the reaction was monitored by using a UV-Vis spectrophotometer $(1.5 \mathrm{~h})$ and the solvent removed under vacuum. ${ }^{1} \mathrm{H}-\mathrm{NMR}$ spectra were recorded for each photomixture and compared with those of the isolated CPDs. 


\subsection{Absorption spectra}

UV-Vis absorption spectra were registered with a simple beam spectrophotometer (Varian Cary 50), using $1 \mathrm{~cm}$ pathway quartz cuvettes.

\subsection{Phosphorescence spectroscopy}

Phosphorescence spectroscopy was performed using a spectrophosphorimeter Photon Technology International (PTI, TimeMaster TM/2003) equipped with a pulsed Xenon lamp. Compounds were dissolved in ethanol, adjusting their absorbance at $c a .0 .8$ at the excitation wavelength $(260 \mathrm{~nm})$ with cuvettes of $1 \mathrm{~cm}$ optical pathway. Measurements were performed in a quartz tube at $77 \mathrm{~K}$.

\subsection{Laser flash photolysis experiments}

A pulsed Nd: YAG SL404G-10 Spectron Laser Systems, using $355 \mathrm{~nm}$ as the excitation wavelength with a pulse duration of $10 \mathrm{~ns}$ and an energy lower than $15 \mathrm{~mJ}$ pulse ${ }^{-1}$ was used to carry out the laser flash photolysis (LFP) experiments. The apparatus consisted of the pulsed laser, a pulsed Lo255 Oriel Xenon lamp, a 77200 Oriel monochromator, an Oriel photomultiplier tube (PMT) housing, a 70705 PMT power supply and a TDS-640A Tektronix oscilloscope. The output signal from the oscilloscope was transferred to a personal computer. Quartz cells of $1 \mathrm{~cm}$ optical path length were employed for the measurements. For quenching experiments compounds $\mathbf{3}, \mathbf{5}$ and 6 were dissolved in $0.7 \mathrm{~mL}$ of anhydrous DMSO (from 0 to $1.3 \mathrm{mM}$ ) and added to a solution of $2 \mathrm{M}$ in PB $10 \mathrm{mM}$ with an absorbance of 0.3 at $\lambda_{\mathrm{exc}}=355 \mathrm{~nm}$, and monitored at $420 \mathrm{~nm}$.

\section{Acknowledgements}

Financial support by the Spanish Government (O. R-A., FPU14/05294 and PGC2018-096684) and Generalitat Valenciana (PROMETEO/2017/075) is gratefully acknowledged.

\section{Associated Content}

Supporting Information. UV absorption spectra, photosensitised irradiations, quenching of $2 \mathrm{M}^{*}$ by the bipyrimidines and NMR data of 3, 3', 4, 5, 7 and $\mathbf{7}^{\prime}$.

\section{References}

1. Marrot, L.; Meunier, J.-R., Skin DNA photodamage and its biological consequences. J. Am. Acad. Dermatol. 2008, 58 (5), S139-S148.

2. Cadet, J.; Douki, T., Formation of UV-induced DNA damage contributing to skin cancer development. Photochem. Photobiol. Sci. 2018, 17 (12), 1816-1841.

3. Mouret, S.; Baudouin, C.; Charveron, M.; Favier, A.; Cadet, J.; Douki, T., Cyclobutane pyrimidine dimers are predominant DNA lesions in whole human skin exposed to UVA radiation. Proc. Natl. Acad. Sci. USA 2006, 103 (37), 13765-13770.

4. Nishisgori, C., Current concept of photocarcinogenesis. Photochem. Photobiol. Sci. 2015, 14 (9), 1713-1721. 
5. Beukers, R.; Eker, A. P. M.; Lohman, P. H. M., 50 years thymine dimer. DNA Repair 2008, $7(3), 530-543$.

6. Lamola, A. A.; Mittal, J. P., Solution photochemistry of thymine and uracil. Science 1966, $154,1560-1561$.

7. Noonan, F. P.; Zaidi, M. R.; Wolnicka-Glubisz, A.; Anver, M. R.; Bahn, J.; Wielgus, A.; Cadet, J.; Douki, T.; Mouret, S.; Tucker, M. A.; Popratiloff, A.; Merlino, G.; De Fabo, E. C., Melanoma induction by ultraviolet $\mathrm{A}$ but not ultraviolet $\mathrm{B}$ radiation requires melanin pigment. Nat Commun 2012, 3, 884.

8. Cadet, J.; Mouret, S.; Ravanat, J.-L.; Douki, T., Photoinduced Damage to Cellular DNA: Direct and Photosensitized Reactionst. Photochem. Photobiol. 2012, 88 (5), 1048-1065.

9. Cuquerella, M. C.; Lhiaubet-Vallet, V.; Bosca, F.; Miranda, M. A., Photosensitised pyrimidine dimerisation in DNA. Chem. Sci. 2011, 2 (7), 1219-1232.

10. Liu, L.; Pilles, B. M.; Reiner, A. M.; Gontcharov, J.; Zinth, W., 2'-Methoxyacetophenone: an efficient photosensitizer for cyclobutane pyrimidine dimer formation. ChemPhysChem 2015, 16 (16), 3483-3487.

11. R. Alzueta, O.; Cuquerella, M. C.; Miranda, M. A., Transient UV-vis absorption spectroscopic characterisation of 2'-methoxyacetophenone as a DNA photosensitiser. Spectrochim. Acta A Mol. Biomol. Spectrosc. 2019, 218, 191-195.

12. Antusch, L.; Gaß, N.; Wagenknecht, H.-A., Elucidation of the Dexter-type energy transfer in DNA by thymine-thymine dimer formation using photosensitizers as artificial nucleosides. Angew. Chem. Int. Ed. 2017, 56 (5), 1385-1389.

13. Vendrell-Criado, V.; Lhiaubet-Vallet, V.; Yamaji, M.; Cuquerella, M. C.; Miranda, M. A., Blocking cyclobutane pyrimidine dimer formation by steric hindrance. Org. Biomol. Chem. 2016, 14 (17), 4110-4115.

14. Vendrell-Criado, V.; Rodríguez-Muñiz, G. M.; Yamaji, M.; Lhiaubet-Vallet, V.; Cuquerella, M. C.; Miranda, M. A., Two-Photon Chemistry from Upper Triplet States of Thymine. J. Am. Chem. Soc. 2013, 135 (44), 16714-16719.

15. Itahara, T., NMR and UV Study of $1,1^{\prime}-\left(\alpha, \omega\right.$-Alkanediyl)bis[thymine] and $1,1^{\prime}-(\alpha, \omega-$ Alkanediyl)bis[uracil]. Bull. Chem. Soc. Jpn. 1997, 70, 2239-2247.

16. Leonard, N. J.; McCredie, R. S.; Logue, M. W.; Cundall, R. L., Synthetic spectroscopic models related to coenzymes and base pairs. XI. Solid state ultraviolet irradiation of 1,1'trimethylenebisthymine and photosensitized irradiation of 1,1'-polymethylenebisthymines. J. Am. Chem. Soc. 1973, 95 (7), 2320-2324.

17. Sandros, K., Transfer of triplet state energy in fluid solutions III. Reversible energy transfer. Acta Chem. Scand. 1964, 18, 2355-2374.

18. Basnak, I.; Balkan, A.; Coe, P. L.; Walker, R. T., The Synthesis of Some 5-Substituted and 5,6-Disubstituted 2'-Deoxyuridines. Nucleosides \& Nucleotides 1994, 13 (1-3), 177-196. 